\title{
RYNEK FINANSOWY JAKO DOBRO WSPÓLNE
}

\section{WPROWADZENIE}

Dynamika obecnych czasów oddziałuje na wszystkie aspekty życia współczesnego człowieka. I choć zmiany sa wpisane w proces ewolucji ludzkości, to jednak ostatnie dziesięciolecia za sprawa globalizacji i towarzyszącego jej rozwoju technologicznego uznać należy za wyjątkowe. Wyjątkowość ta przejawia się między innymi we wzrastajacej roli nowych form komunikacji, ilości danych, do których analizy każdego dnia zmuszany jest przeciętny człowiek, a także - co istotne $\mathrm{z}$ punktu widzenia niniejszego opracowania - finansjalizacji życia codziennego, która określić można jako proces przenikania sfery ekonomicznej do sfery realnej ${ }^{1}$. Odnieść można bowiem wrażenie, że aktywność współczesnego człowieka, mieszkającego przykładowo w Europie, jest w głównej mierze skoncentrowana na pozyskiwaniu pieniądza, wykorzystywanego do zakupu (niekiedy na kredyt) kolejnych dóbr konsumpcyjnych, co niesie za sobą konieczność ich utrzymania. Czasami ów proces wydaje się nie mieć końca, a istotna rolę odgrywaja w nim rynki finansowe oddziałujące zarówno w wymiarze krajowym, jak i samorządowym ${ }^{2}$, które - jak słusznie zauważa się w literaturze - przyczyniły się do kryzysu wartości i kryzysu zaufania, przy czym zwłaszcza ten ostatni doprowadził do osłabienia twórczego myślenia i zrodził obawy o przyszłość, a w dłuższej perspektywie godzi w godność człowieka ${ }^{3}$.

Pozytywnym efektem przytaczanych wydarzeń jest dyskurs dotyczący wielu problemów, w tym roli państwa w gospodarce ${ }^{4}$, ale także i konieczności redefinicji postrzegania człowieka jako elementu systemu gospodarczego oraz spojrzenia na niego przez pryzmat realistycznej perspektywy antropologicznej. Człowiek w owym ujęciu powinien być postrzegany zarówno w wymiarze egocentrycznym, jak i relacyjnym, a więc być skierowany na siebie,

${ }^{1}$ M. Wrzesiński, Finansjalizacja gospodarki-fakty czy mity?, w: K. Ostaszewski, E. Kosycarz (red.), Rozwój nauki o finansach. Stan obecny i pożadane kierunki jego ewolucji, Warszawa 2010, s. 293-305.

${ }^{2}$ Zob. np. P. Zawadzka, Instrumenty finansowe $w$ gospodarce gminy, Warszawa 2015, passim. Zob. także T. Nieborak, S. Huczek, Instrumenty pochodne $w$ działalności samorzadu terytorialnego - podstawowe zagadnienia, „Finanse Komunalne” 2004, nr 12, s. 2-13.

${ }^{3}$ P. H. Dembinski, S. Beretta, Kryzys ekonomiczny i kryzys wartości, Kraków 2014, s. $107-113$.

${ }^{4}$ M. Ratajczak, Spór o role państwa $w$ gospodarce, „Ruch Prawniczy, Ekonomiczny i Socjologiczny" 79, 2017, z. 1, s. 5-23. 
ale również na wspólnotę, w której funkcjonuje ${ }^{5}$. Obecnie nie sposób ocenić efektu tejże dyskusji. Zgodzić należy się jednak z teza, że mamy współcześnie do czynienia $\mathrm{z}$ okresem jakościowych przewartościowań, uzasadniajacych ważne przemiany nie tylko w teorii, lecz także w systemie społecznych wartości ${ }^{6}$. Zauważalne one zaczynają być także w nauce prawa, w tym prawa finansowego, w ramach którego w ostatnich latach widoczna jest emancypacja prawa rynku finansowego - jego przedstawiciele podejmuja wysiłki zrozumienia istoty prawa jako zjawiska społecznego, regulującego funkcjonowanie rynku finansowego.

$\mathrm{W}$ opinii autora $\mathrm{w}$ badaniach tych konieczne jest zwrócenie uwagi nie tylko na problem etyki normatywnej, opartej na przepisach wyznaczających granice działania (lub niedziałania), lecz także na problem etyki cnoty, odwołujacej się do określonych fundamentalnych wartości ${ }^{7}$. Myśl ta stała się inspiracja do powstania niniejszego artykułu, którego celem jest ukazanie istoty rynku finansowego osadzonego w szerszym kontekście, tj. dobra wspólnego, identyfikowanego niekiedy z interesem publicznym ${ }^{8}$. Analizę taką uznać należy za konieczną i przydatna z punktu widzenia przeszłych i obecnych sporów prawnych związanych z rynkiem finansowym. Tytułem przykładu wskazać należy na problemy: wykorzystania kontraktów opcji, tzw. frankowiczów, polisolokat $^{9}$, a także Amber Gold. Wszystkie wymienione przykłady łączą się bowiem z problemem dobra wspólnego, sposobu jego rozumienia, definiowania, zakresu, a także ewentualnych konsekwencji (i odpowiedzialności) za jego naruszenie zarówno w wymiarze krajowym, jak i zagranicznym.

\section{RYNEK FINANSOWY - UJĘCIE PRAWNO-EKONOMICZNE}

Analizę istoty dobra wspólnego ujmowanego w perspektywie rynku finansowego rozpocząć należy od charakterystyki tego rynku. Powszechnie wydaje się, że pojęcie rynku finansowego nie budzi większych kontrowersji. Jest on czymś oczywistym, nierozerwalnym elementem współczesnego krajobrazu gospodarczego, pełniącym określone funkcje. Sprawa komplikuje się jednak w sytuacji, gdy konieczne jest określenie zakresu definicyjnego pojęcia „rynek finansowy”, co ma fundamentalne znaczenie $\mathrm{z}$ punktu widzenia tworzenia i stosowania prawa go dotyczącego. Prawodawca bowiem, wprowadzając określone prawa

${ }^{5}$ A. Glapiński, Przedmowa, w: P. H. Dembinski, S. Beretta, op. cit., s. 9-10.

${ }^{6}$ A. Nadolska, Od prawa finansowego do prawa rynku finansowego - zarys zmian, „Monitor Prawa Bankowego" 2016, nr 1, s. 65. Zob. także D. W. Snyder Belousek, Market exchange, self-interest, and the common good: financial crisis and moral economy, „Journal of Markets \& Morality" 13(1), 2010, s. 83-100.

${ }^{7}$ N. Szutta, Status wspótczesnej etyki cnót, „Diametros” 2004, nr 1 (wrzesień), s. 70-84.

${ }^{8}$ Więcej na ten temat w: M. Stahl, Dobro wspólne $w$ prawie administracyjnym, w: J. Boć, A. Chajbowicz (red.), Nowe problemy badawcze w teorii prawa administracyjnego, Wrocław 2009, s. $47-60$.

${ }^{9}$ A. Michór, Ubezpieczenia na życie z ubezpieczeniowym funduszem kapitałowym a ochrona konsumenta, „Bezpieczny Bank” 2015, nr 1, s. 156-160. 
i obowiązki dotyczące szeroko rozumianych uczestników tego rynku (a więc zarówno instytucji finansowych oraz osób nimi zarządzajacych, jak i konsumentów usług przez te instytucje oferowanych), musi zakreślić pole swojej ingerencji. Zwracano na to uwagę między innymi w trakcie dyskusji, która toczyła się w okresie poprzedzającym przyjęcie jednego z najważniejszych aktów prawnych polskiego rynku finansowego, a mianowicie ustawy o nadzorze nad rynkiem finansowym ${ }^{10}$, będącej podstawą do powołania do życia Komisji Nadzoru Finansowego. W opinii z 4 lipca 2006 r. na temat tej ustawy Lesław Góral, nawiązując do tytułu projektu ustawy (ostatecznie zaakceptowanego przez prawodawcę), zwracał uwagę, że ze względu na skuteczność sprawowanego nadzoru w przygotowywanym akcie prawnym powinna znaleźć się definicja prawna, a nie ekonomiczna „rynku finansowego” ${ }^{11}$. Wskazał przy tym na działania przedstawicieli doktryny, w szczególności prawa publicznego, których celem było stworzenie tego rodzaju definicji. Dominujące w tym względzie było jednak w opinii cytowanego autora posiłkowanie się ekonomicznym i organizacyjnym rozumieniem rynku. Zgodzić należy się przy tym z jego teza, że „[k]onieczność wypracowania w doktrynie prawa ogólnej definicji wynika stą, że pojęcie rynku finansowego zaczerpnięte z języka potocznego nie może być używane jako narzędzie poznania w badaniu zagadnień związanych funkcjonowaniem publicznoprawnych instytucji ochrony rynku finansowego, zaś powołanie sformułowanych w naukach ekonomicznych okazać się może niewystarczające" ${ }^{12}$. Tytułem przykładu wskazać można na definicje ekonomiczne traktujace rynek finansowy jako ogół transakcji związanych z przemieszczaniem kapitałów pieniężnych ${ }^{13}$, czy też zespół instytucji dokonujacych obrotu kapitałem ${ }^{14}$. Ważnym osiagnięciem nauki ekonomii jest także wypracowanie katalogu funkcji pełnionych przez rynek finansowy $\mathrm{w}$ gospodarce.

Do najczęściej wymienianych $\mathrm{w}$ literaturze funkcji rynku finansowego zalicza się: funkcję pośrednictwa, funkcję kumulacji kapitałów, funkcję rozliczeniowa, a także funkcję zarządzania aktywami i pasywami. O istocie wyodrębnienia wymienionych przykładowych funkcji świadczy fakt, że sa one uwzględniane przez prawodawcę w procesie prawotwórczym dotyczącym rynku finansowego. Za przykład posłużyć mogą regulacje w zakresie norm ostrożnościowych, których znaczenie dla funkcjonowania banków wynika $\mathrm{z}$ ich roli $\mathrm{w}$ procesie zarządzania aktywami i pasywami oraz potencjalnego ryzyka z tym związanego ${ }^{15}$. Prawodawca, widząc tę zależność i możliwe negatywne konsekwencje dla stabilności systemu finansowego, zdecydował się na włączenie w ramy prawa problematyki wymogów ostrożnościowych. Należy podkreślić w tym miejscu, że inspiracją do tych działań była także

${ }^{10}$ Ustawa o nadzorze finansowym z 21 lipca 2006 r., Dz. U. 2016, poz. 174 (dalej jako: UKNF).

${ }^{11}$ L. Góral, Opinia do projektu ustawy o nadzorze nad rynkiem finansowym (druk $\mathrm{nr} 654$ ), Biuro Analiz Sejmowych, Warszawa 2006, s. 2-3.

${ }^{12}$ Ibidem, s. 3.

${ }^{13}$ W. Bień, Rynek papierów wartościowych, Warszawa 2004, s. 183.

${ }^{14}$ A. Samborski, Rynki papierów wartościowych w krajach Unii Europejskiej, Katowice 2004, s. 9.

${ }_{15}$ M. Olszak, Bankowe normy ostrożnościowe, Białystok 2011, passim. 
aktywność takich podmiotów, jak Bazylejski Komitet ds. Nadzoru Bankowego, który jako forum przedstawicieli organów nadzoru nad rynkiem finansowym z wielu państw przyczynił się do wypracowania wskaźników pomocnych w procesie regulacji, nadzoru oraz zarządzania ryzykiem na rynku bankowym. Wskaźniki te (nazywane także standardami regulacyjnymi i zaliczane do tzw. funkcjonalnych źródeł prawa ${ }^{16}$, identyfikowane obecnie pod nazwa Basel III lub umowy bazylejskiej) stały się następnie inspiracją do działań prawodawczych majacych na celu ich wprowadzenie do wewnętrznych porządków prawnych. W przypadku Unii Europejskiej ${ }^{17}$ między innymi za sprawą tzw. pakietu CRDIV/CRR ${ }^{18}$.

Dogłębna analiza prawodawstwa unijnego dotyczącego funkcjonowania unijnego rynku finansowego (a obejmujacego już przeszło 70 aktów prawnych) prowadzi do wniosku, że także prawodawca europejski nie sprostał wyzwaniu ani nie stworzył uniwersalnej definicji rynku finansowego. Przyją on przy tym koncepcję polegająca na opisywaniu tego rynku przez aktywności podejmowane na nim przez poszczególne instytucje finansowe. W literaturze przedmiotu prezentowany jest pogląd, że tego rodzaju technika określania statusu prawnego instytucji finansowej przez charakterystykę specyfiki jej działalności za pomoca przypisania jej właściwego katalogu usług finansowych, które ma ona prawo świadczyć, pozwala na odtworzenie konstrukcji rynku finansowego w ujęciu przedmiotowym, przez pryzmat określonych usług finansowych ${ }^{19}$. Znając więc przedmiot działalności, jesteśmy w stanie przyporządkować jemu określony podmiot. W rezultacie ujmowanie przez prawodawcę $\mathrm{w}$ ramy prawne kolejnych rodzajów pojawiajacych się aktywności prowadzi do wypełniania zbioru, który moglibyśmy określić jako rynek finansowy.

Także polski prawodawca w cytowanej już UKNF, mimo przytaczanych głosów doktryny, nie zdecydował się na stworzenie kompleksowej definicji „rynku finansowego”, odnosząc to pojęcie jedynie do poszczególnych segmentów rynku będących przedmiotem nadzoru (art. 2 ust. 2 UKNF). Sformułować należy tezę, że mimo przyjęcia tego rodzaju filozofii regulacyjnej w przyszłości konieczne będzie jednak podjęcie próby zdefiniowania rynku finansowego jako instytucji prawnej, której definicja powinna stanowić myślowe odzwierciedlenie i całościowe ujęcie istotnych zjawisk regulowanych przez prawo ${ }^{20}$. Wynika to przede wszystkim ze znaczenia współczesnych

${ }^{16}$ Zob. R. Kaszubski, Funkcjonalne źródta prawa bankowego publicznego, Warszawa 2006.

${ }_{17}$ M. Żurek, Kapitat regulacyjny w Dyrektywie CRDIV oraz Rozporzqdzeniu CRR-odpowiedź normatywna na kryzys finansowy w UE, „Monitor Prawa Bankowego” 2014, nr 6, s. 32-51.

${ }^{18}$ Dyrektywa Parlamentu Europejskiego i Rady 2013/36/UE z 26 czerwca 2013 r. w sprawie warunków dopuszczenia instytucji kredytowych do działalności oraz nadzoru ostrożnościowego nad instytucjami kredytowymi i firmami inwestycyjnymi, zmieniająca dyrektywę 2002/87/WE i uchylająca dyrektywy 2006/48/WE oraz 2006/49/WE, OJ L 176/338; rozporządzenie Parlamentu Europejskiego i Rady (UE) nr 575/2013 z 26 czerwca 2013 r. w sprawie wymogów ostrożnościowych dla instytucji kredytowych i firm inwestycyjnych, zmieniajace rozporządzenie (UE) nr 648/2012, OJ L 176/1.

${ }_{19}$ D. Wojtczak, Ustugi bankowe w regulacjach Unii Europejskiej, Warszawa 2012, s. 15-54.

${ }^{20}$ L. Góral, Opinia do projektu..., s. 3. 
rynków finansowych dla funkcjonowania państwa i relacji, jaka istnieje pomiędzy rynkiem finansowym a systemem społecznym. Pierwszy z wymienionych jest bowiem częścią większej całości, a więc systemu finansowego, który z kolei uczestniczy w tworzeniu systemu gospodarczego, ten zaś jest częścią system społecznego. Oznacza to tym samym, że jakiekolwiek zakłócenia na rynku finansowym prędzej czy później będą miały swoje konsekwencje w systemie społecznym. Dobitnym tego przykładem sa kryzysy finansowe, których skutki najbardziej odczuwaja przeciętni ludzie ${ }^{21}$. Kryzysy, ale także i wszelkiego rodzaju zakłócenia związane z omawianym rynkiem sa, były i z pewnością będą również w przyszłości przyczynkiem do dochodzenia praw (odszkodowań) przez podmioty, które poniosły wskutek nich określone straty. I choć sprawy tego rodzaju nie wydaja się powszechne oraz nagłaśniane szerszej opinii publicznej, to jednak zdarzają się i nie pozostają bez wpływu na funkcjonowanie państw i społeczeństw.

Tytułem przykładu wskazać można na podjętą niedawno przez Instytut Arbitrażowy przy Izbie Handlowej w Sztokholmie decyzję nakazująca państwu polskiemu zapłatę ponad dwóch miliardów złotych odszkodowania funduszowi inwestycyjnemu Abris Capital Partners, któremu Komisja Nadzoru Finansowego kilka lat temu nakazała sprzedaż akcji FM Banku w związku z niewypełnieniem przez ten fundusz zobowiązań inwestorskich wobec polskiego organu nadzoru. Sprawa ta jest niezwykle ciekawa, biorac pod uwagę kwotę kary, jak i źródło jej pokrycia w sytuacji, gdy odpowiedzialność za działania organu nadzoru ponosi Skarb Państwa. Sprawa ta była już przedmiotem debaty przy okazji rozpatrywania przez polski Trybunał Konstytucyjny wniosku Rzecznika Praw Obywatelskich z 15 stycznia 2009 r. o zbadanie zgodności art. 10 ust. 3 oraz art. 74 ust. 2 i 3 ustawy o nadzorze nad rynkiem finansowym z art. 153 ust. 1 Konstytucji RP, dotyczącego funkcjonowania służby cywilnej w Polsce; wniosek doprowadził do wydania orzeczenia w tej sprawie $^{22}$. Niezwykle istotne okazało się w niej między innymi określenie statusu prawnego Komisji Nadzoru Finansowego ${ }^{23}$, który może mieć następ-

${ }^{21}$ Zob. np. P. Masiukiewicz, Klasyczny run na kasy w banku hipotecznym Northern Rock, w: idem (red.), Międzynarodowe bankructwa i afery bankowe, Warszawa 2010, s. 143-160.

22 Wyrok TK z 15 czerwca 2011 r., K 2/09, OTK-A 2011, nr 5, poz. 42, Dz. U. 2011, Nr 134, poz. 788, Lex nr 950591.

${ }_{23}$ P. Stanisławiszyn, Nadzór i kontrola nad Komisja Nadzoru Finansowego, w: P. Karpuś, J. Węcławski (red.), Rynek finansowy. Inspiracje z integracji europejskiej, Lublin 2008, s. 35 i n.; A. Michór, Komisja Papierów Wartościowych i Giełd jako centralny organ administracji rzadowej $w$ zakresie publicznego obrotu papierami wartościowymi. Wybrane zagadnienia, Acta Universitatis Wratislaviensis, 2005, nr 2724, s. 199 i n.; A. Michór, Przesłanki ingerencji państwa $w$ organizowanie $i$ organizacje obrotu instrumentami finansowymi, „Opolskie Studia Administracyjno-Prawne" 5, 2008, s. 195 i n.; R. W. Kaszubski, Komisja Nadzoru Bankowego - nowa jakość w administracji publicznej, „Glosa” 1998, nr 11, s. 5-12; Z. Szpringer, Komisja Nadzoru Bankowego $w$ systemie prawnym $i$ bankowym, „Zeszyty Prawnicze Biura Studiów i Ekspertyz Kancelarii Sejmu” 2006, nr 2, s. 233 i n.; R. Tupin, Status prawny i kompetencje prawotwórcze organów Narodowego Banku Polskiego i Komisji Nadzoru Bankowego, „Przegląd Ustawodawstwa Gospodarczego" 1998, nr 7-8, s. 2 i n. 
nie znaczenie w sprawach dotyczących odpowiedzialności z tytułu działania (lub zaniechania) organu nadzoru nad rynkiem finansowym ${ }^{24}$.

Analogiczny problem był przedmiotem analizy Trybunału Sprawiedliwości Unii Europejskiej w wydanym wyroku w sprawie Peter Paul i inni przeciwko Republika Federalna Niemiec (C-222/02) ${ }^{25}$. Podobnie jak w przypadku wspomnianego wcześniej wyroku polskiego TK, w sprawie tej TSUE musiał rozważyć kilka wątków, w tym kwestię odpowiedzialności organu nadzoru oraz wziać pod uwagę ewentualne konsekwencje społeczne swojego orzeczenia ${ }^{26}$. W przedmiotowej sprawie konieczne stało się również skonfrontowanie dwóch fundamentalnych interesów zasługujących na ochronę. Mowa w tym miejscu o interesie publicznym (utożsamianym niejednokrotnie $\mathrm{z}$ dobrem wspólnym) oraz interesie jednostek ${ }^{27}$. Problem, który pojawił się przy tej okazji, sprowadzał się między innymi do rozważenia, czy rynek finansowy, będący częścia systemu społecznego, powinien zasługiwać na szczególną ochronę ze względu na interes większej ilości jednostek korzystających z jego funkcji, czy w określonych sytuacjach dopuszczalna jest ochrona tylko wybranych spośród ogółu jednostek poszkodowanych kosztem szerszej grupy społecznej. Mimo że od wydania przytaczanego orzeczenia minęło kilka lat, wątpliwości jemu towarzyszące są w dalszym ciąu aktualne. Odnieść je bowiem można do budzącego duże emocje tzw. problemu frankowiczów w Polsce, który prowokuje do licznych pytań. Czy bowiem biorąc pod uwagę interes tych osób, należy rozważyć pełne wsparcie dla nich, a koszty przerzucić na system bankowy? Jeżeli tak, to czy system bankowy będzie w stanie tego rodzaju operację przetrwać bez zachwiana swojej stabilności? Stabilności, która - jak zostanie to wykazane w dalszej części artykułu - wypełnia w ocenie autora treść pojęcia dobra wspólnego, a której utrata w wyniku tzw. efektu zarażania mogłaby wpłynąć na funkcjonowanie całego organizmu gospodarczego państwa, a więc tym samym i organizmu społecznego. Co więcej, czy tego rodzaju rozwiązanie byłoby sprawiedliwe? Czy jednak nie jest tak, że sektor bankowy wykorzystał słabszą pozycję swoich klientów oraz ich mniejszą percepcję potencjalnego ryzyka, a w związku z tym powinien w określonym stopniu partycypować w ponoszonych przez klientów kosztach?

Powyższe pytania sa zaledwie kilkoma, jakie pojawiają się przy okazji analizy istoty rynku finansowego, jako przedmiotu coraz większego zainteresowania przedstawicieli prawa finansowego, w ramach którego od kilkunastu lat

${ }^{24}$ T. Nieborak, Status prawny Komisji Nadzoru Finansowego w świetle orzeczenia Trybunału Konstytucyjnego z dnia 15 czerwca 2011 roku (sygn. K 2/09), w: L. Etel, M. Tyniewicki (red.), Ksiega Pamiqtkowa Pana Profesora E. Ruśkowskiego, Białystok 2012, s. 573-582.

${ }_{25}$ Wyrok ETS z 12 października 2004 r. w sprawie C-222/02, Peter Paul i inni przeciwko Republika Federalna Niemiec, ECR 2004, s. I-9425.

${ }^{26}$ E. Murzyn, Odpowiedzialność odszkodowawcza za naruszenie prawa UE przez organy nadzoru bankowego w Niemczech, „Europejski Przegląd Sądowy” 2012, nr 11, s. 25-32.

${ }^{27}$ Więcej na ten temat w: T. Nieborak, Stabilność polskiego systemu finansowego a odpowiedzialność organów go nadzorujacych w aspekcie sprawy Peter Paul $i$ inni przeciwko Republika Federalna Niemiec (C-222/02), w: P. J. Lewkowicz, J. Stankiewicz (red.), Konstytucyjne uwarunkowania tworzenia $i$ stosowania prawa finansowego i podatkowego, Białystok 2010, s. 652-666. 
zauważalne jest wyodrębnianie się specjalizacji, tj. prawa rynku finansowego ${ }^{28}$. Uzasadnieniem jego istnienia, jak słusznie zauważa Małgorzata Fedorowicz, jest konieczność tworzenia pewnego rdzenia poglądów (teorii) i odnalezienia się w gąszczu nowych, nie zawsze do końca zrozumiałych i spójnych regulacji rynku finansowego (w szczególności unijnego). Działalność ta pozwoli ukształtować normatywny i teoretyczny szkielet pojęć, instytucji, a także instrumentów oddziaływania na rynek ${ }^{29}$. Wśród pojęć tych znajduje się „również rynek finansowy”, który zgodnie z propozycjami doktryny ${ }^{30}$ powinien być ujmowany szeroko. Swym zakresem definicyjnym winien on odnosić się zarówno do strony przedmiotowej (instrumentów finansowych), jak i podmiotowej (instytucji, klientów, konsumentów), tym samym ma być miejscem spotkania się podaży i popytu na pieniądz (kapitał), gdzie określone rodzaje podmiotów gospodarczych przy wykorzystaniu odpowiedniej infrastruktury podejmują ogół działań o charakterze ekonomicznym i związanych z nimi czynności prawnych, przyjmujacych postać określonych instrumentów finansowych, wykorzystywanych zarówno w interesie tych instytucji, jak i ich klientów (konsumentów), których ostatecznym celem powinno być zwiększenie wartości zainwestowanego kapitału.

Zdaniem autora, z uwagi na znaczenie współczesnych rynków finansowych w życiu człowieka, konieczne jest w ich analizie (w szczególności prawnej) postrzeganie owych rynków w szerszym, aksjologicznym wymiarze. Jednym z elementów, który pojawia się w tego rodzaju ujęciu, jest problem dobra wspólnego i jego recypowania na grunt wspomnianej teorii prawa rynku finansowego. Być może za sprawą złudnych oczywistości w rozumieniu rynku finansowego nie doczekał się on jak dotąd analizy, która pozycjonowałaby go w świetle koncepcji dobra wspólnego i potrafiłaby znaleźć odpowiedź na pytania: Czy rynek ten sam w sobie jest dobrem wspólnym? Czy być może na dobro to składaja się określone wartości, które towarzyszyć powinny funkcjonowaniu tego rynku i realizacji przez niego określonych funkcji?

28 E. Fojcik-Mastalska, Prawo rynku finansowego w systemie prawa, w: A. Jurkowska-Zeidler, M. Olszak (red.), Prawo rynku finansowego. Doktryna, instytucje, praktyka, Warszawa 2016 , s. 19-26; C. Kosikowski, Nowe prawo rynku finansowego Unii Europejskiej, w: A. Jurkowska-Zeidler, M. Olszak (red.), op. cit., s. 27-38; C. Kosikowski, M. Olszak, Od prawa bankowego do prawa rynku finansowego, w: J. Głuchowski (red.), System prawa finansowego, t. 4, Warszawa 2010, s. 224-250; Z. Ofiarski, Rola soft law w regulacji rynku finansowego na przykładzie rekomendacji i wytycznych Komisji Nadzoru Finansowego, w: A. Jurkowska-Zeidler, M. Olszak (red.), op. cit., s. 137-160; M. Fedorowicz, Nadzór nad rynkiem finansowym Unii Europejskiej, Warszawa 2013, passim; E. Rutkowska-Tomaszewska, Ochrona prawna klienta na rynku usług bankowych, Warszawa 2013; A. Nadolska, Komisja Nadzoru Finansowego w nowej instytucjonalnej architekturze europejskiego nadzoru finansowego, Warszawa 2014; B. Bator, A. Zalcewicz, Ustawa o ustugach płatniczych. Komentarz, Warszawa 2016. Więcej na ten temat w: T. Nieborak, Tworzenie $i$ stosowanie prawa rynku finansowego a proces ekonomizacji prawa, Poznań 2016, s. 75-93.

${ }^{29}$ M. Fedorowicz, Rola $i$ zadania teorii prawa rynku finansowego UE, „Bezpieczny Bank” 2016, nr 1, s. 116-117.

${ }^{30}$ Poniższa definicja uwzględnia elementy sformułowane w definicjach rynku finansowego zaproponowanych przez L. Górala i P. Zapadkę. Zob. L. Góral, Opinia do projektu..., s. 2, oraz P. Zapadka, Aspekty prawne funkcjonowania rynku finansowego $w$ Polsce, „Bank i Kredyt” 2002, nr 1, s. 28. 


\section{DOBRO WSPÓLNE A RYNEK FINANSOWY - PRÓBA REKONSTRUKCJI ZALEŻNOŚCI}

Analiza istoty rynku finansowego będącego fundamentalnym elementem systemu społecznego i rozpatrywanego w perspektywie dobra wspólnego wymaga krótkiej refleksji na temat istoty prawa. Prawa ujmowanego jako zjawisko kulturowe, przynależne strukturom społecznym i będące nośnikiem głębokich struktur i podstawowych wartości ${ }^{31}$. Warto w tym miejscu wskazać na niezwykle ważną i interesujacca pracę autorstwa Romana Stasikowskiego, w której zaprezentowane zostały relacje pomiędzy prawem a jednostką oraz społeczeństwem a gospodarka ${ }^{32}$. Na szczególną uwagę zasługuje wyartykułowanie przez autora watku aksjologicznego i antropologicznego. Ten ostatni jest także widoczny w rozwijanej w ostatnich latach behawioralnej koncepcji prawa, której aplikacja możliwa jest w przypadku prawa rynku finansowe$\mathrm{go}^{33}$. W procesie jego tworzenia i stosowania powinno się bowiem ujmować także elementy pozaprawne, behawioralne, które odnosić można przykładowo do skutków obowiązywania takiego, a nie innego prawa, a także wpływu na prawo istniejącej i ewoluującej rzeczywistości. Na treść prawa ma wpływ, jak słusznie zauważa R. Stasikowski, również to, jaka jest dana jednostka (będaca adresatem tego prawa), a więc jak myśli, pojmuje i rozumie otaczająca ja rzeczywistość, a także jaką rolę w procesie percepcji prawa odgrywają emocje. Relacje pomiędzy rzeczywistością a jednostką są dwukierunkowe. Z jednej bowiem strony to rzeczywistość wpływa na tę jednostkę, z drugiej natomiast - jednostka ma możliwość kreowania tejże rzeczywistości. W ostatnim przypadku nie bez znaczenia będzie jej światopogląd czy też wychowanie ${ }^{34}$, kształtujące systemy wartości, których nośnikiem jest człowiek. Analiza większości kryzysów finansowych prowadzi także do człowieka, będącego ich źródłem. Poddawany emocjom i żądzy posiadania, zaślepiony fetyszem pieniądza dopuszcza się on naruszeń, które godzą w dobro wspólne. To bowiem wartości ludzkie i społeczne przesądzają o podejmowanych przez człowieka działaniach w życiu codziennym, o jego światopoglądzie, wyborach politycznych i działalności społecznej ${ }^{35}$. „To one także przesądzają o rozumieniu istoty dobra wspólnego, konieczności troski o nie, troski o społeczeństwo i gospodarkę. Wartości te stają się również bazą kształtowania norm prawnych"36, a więc prawa.

Piszac o prawie i wartościach, nie sposób nie wspomnieć o różnicy, jaka wypływa z podejścia kognistywistycznego i akognitywistycznego do problemu wartości i ich poznania. Pierwsze $\mathrm{z}$ nich w uproszczeniu zakłada niezmienne istnienie wartości, stanowiących zarazem trwały i pewny układ odniesienia,

31 R. Stasikowski, Prawo a jednostka, społeczeństwo i gospodarka, „Przegląd Prawa Publicznego" 2012, nr 9, s. 53.

32 Ibidem, s. 53-74.

${ }^{33}$ Więcej na ten temat w: T. Nieborak, Creation and Enforcement of Financial Market Law in the Light of the Economisation of Law, Poznań 2016, s. 155-172.

${ }^{34}$ R. Stasikowski, op. cit., s. 53-54.

35 Ibidem, s. 67.

36 Ibidem. 
na bazie którego tworzona jest kultura ludzka, a zatem również jej element prawo. Ów absolutyzm aksjologiczny jest obcy przedstawicielom drugiej z koncepcji (tj. akognitywizmu), uznajacym, że wartości nie mogą być przedmiotem poznawania, ale ludzkiej kreacji ${ }^{37}$. Ta odmienność poglądów towarzyszy także dyskusji na temat dobra wspólnego. Dobra wspólnego, które intuicyjnie powszechnie rozumiane, okazuje się wyzwaniem przy próbie jego precyzyjnego zdefiniowania. Encyklopedyczne znaczenie dobra wspólnego sprowadza je do wartości zbiorowej, która osiagana jest przez wspólnoty ludzkie w związku z rozwijaniem naturalnych możliwości ich członków, zaspokajaniem ich indywidualnych interesów lub respektowaniem posiadanych przez nich uprawnień jednostkowych przy jednoczesnej dbałości o zbliżanie całej wspólnoty ku właściwym jej celom ${ }^{38}$. W definicji tej należy zwrócić uwagę na element aksjologiczny, który przebija się także i w innych definicjach dobra wspólnego. Tytułem przykładu, Marek Piechowiak, pisząc o dobru wspólnym, definiuje je także jako wartość, pewien realny lub projektowany stan rzeczy, który na gruncie prawa materializuje się pod postacią klauzuli dobra wspólnego ${ }^{39}$. Wskazuje przy tym na prawnonaturalny jej charakter i koncepcję wartości uznanych za obiektywnie ugruntowane. Dekodowanie pojęcia dobra wspólnego nie jest łatwe i realizowane może być na gruncie języka prawnego, prawniczego, a także aksjologicznego ${ }^{40}$.

W tym ostatnim przypadku autorzy zazwyczaj sięgają do nauki społecznej Kościoła rzymskokatolickiego, która podkreśla między innymi harmonię, jaka musi istnieć pomiędzy dobrem jednostki a dobrem wspólnym, nie kwestionując przy tym roli instytucji państwa i prawa, zwracaja jednak słusznie uwage na potrzebę uwzględnienia porządku moralnego ${ }^{41}$. Na zależność tę wskazał także papież Benedykt XVI w wydanej w 2009 r. (a więc w czasie kryzysu finansowego) encyklice Caritas in veritate. Nawiąując do kryzysu gospodarczego, zwrócił uwagę na szanse, jakie wyniknąc moga z owych zawirowań. Upatrywał ich w możliwości kreowania nowych reguł opartych na solidarności i zaufaniu. W pkt 5 encykliki czytamy, że „bez prawdy, bez zaufania i miłości do prawdy, nie ma świadomości i odpowiedzialności społecznej, a działalność społeczna zostaje uzależniona od prywatnych interesów i logiki władzy, prowadzac do dzielenia społeczeństwa, a tym bardziej społeczeństwa zmierzającego do globalizacji, w trudnych momentach jak obecnie”. Słowa te znajdują swoje odzwierciedlenie w sytuacji rynku finansowego, którego kryzys, jak

${ }^{37}$ T. Stawecki, P. Winczorek, Wstep do prawoznawstwa, Warszawa 2003, s. 25-26.

${ }^{38}$ Hasło „dobro wspólne”, w: Wielka encyklopedia, t. 7, Warszawa 2002, s. 233. Zob. także M. Tuliusz Cyceron, O państwie. O prawach, Kęty 1999, s. 74; M. A. Krapiec, Struktura bytu. Charakterystyczne elementy systemu Arystotelesa i Tomasza z Akwinu, Lublin 1963, s. 285.

${ }^{39}$ M. Piechowiak, Dobro wspólne jako fundament polskiego porzadku konstytucyjnego, Warszawa 2012 , s. 38 .

${ }^{40}$ W. Łączkowski, Ekonomiczne i socjalne prawa człowieka a dobro wspólne, w: Godność człowieka a prawa ekonomiczne i socjalne. Ksiega Jubileuszowa wydana w piętnasta rocznicę ustanowienia Rzecznika Praw Obywatelskich, Warszawa 2003, s. 38.

${ }^{41}$ A. Gołębiowska, Refleksje nad konstytucyjna zasada dobra wspólnego w kontekście myślenia religijnego i orzecznictwa Trybunału Konstytucyjnego, „Świat i Słowo” 2015, nr 1, s. 189-191. 
podkreślono wcześniej, rozpoczą się od kryzysu wartości i zaufania, z których ostatnie traktowane powinno być jako wartość naczelna rynku finansowego.

$\mathrm{Na}$ zaufaniu bowiem oparte są relacje uczestników rynku finansowego, a więc i jego bezpieczeństwo oraz stabilność. Samo zaufanie, podobnie jak dobro wspólne, jest przedmiotem zainteresowania nauki od setek lat i doczekało się wielu koncepcji jego definiowania ${ }^{42}$. Jedna $\mathrm{z}$ nich opiera się na analizie funkcjonalnej i jest autorstwa Niklasa Luhmanna, który pisząc o zaufaniu, przyjął, że ze względu na złożoność współczesnego świata niezbędnymi czynnikami do funkcjonowania w nim człowieka sa wiara i zaufanie. Okazywanie natomiast zaufania jest antycypacją przyszłości i służy pewności przyszłości ${ }^{43}$. Tomasz Stawecki, pisząc o relacji prawo-zaufanie, wskazuje na cztery, jakże ważne, typy powiązań pomiędzy ludzką relacją zaufania a porządkiem prawnym. Z punktu widzenia regulacji rynku finansowego i uznania zaufania za wartość naczelną na nim obecna, cenna jest druga z wyróżnionych przez cytowanego autora relacji, sprowadzajaca się do sytuacji, w której zaufanie postrzegane jest jako przedmiot ochrony, uznana wartość prawna, bez której można żyć, bez której istnienia jednak prędzej czy później następuje delegitymizacja określonych instytucji prawnych, a nawet, jak uważa autor prezentowanej koncepcji, odrzucenie całego porządku prawnego ${ }^{44}$. Używajac klasyfikacji Daniela P. Sulmasy, tak ujmowane zaufanie można by zakwalifikować do kategorii integralnego dobra wspólnego, a więc dobra wspólnego, które powstaje w wyniku ludzkiej interakcji i nie może być podzielone na jednostkowe dobra $^{45}$. Tezę tę potwierdza definicja zaufania zaproponowana przez Piotra Sztompkę, który pisząc o nim, stwierdza, że „zaufanie to szczególny, ludzki pomost do niepewnego, przyszłego świata, w którym centralną rolę odgrywaja inni ludzie. Nie mogę na ten pomost nie wejść, bo inni, choć niepewni w swoich intencjach czy reakcjach, sa mi potrzebni" ${ }^{46}$.

Znaczenie zaufania dostrzega także prawodawca polski i europejski. W większości najważniejszych aktów europejskiego (polskiego) prawa ryn$\mathrm{ku}$ finansowego odnajdujemy odniesienie do zaufania. Prawodawca czyni to, mówiąc o: „utraconym zaufaniu uczestników rynku”, „banku jako instytucji zaufania publicznego”, „zaufaniu jako elemencie utrzymania stabilności”. Zaufanie jako wartość naczelna rynku finansowego wypełnia przy tym treść interesu publicznego, z którym w naukach prawa publicznego utożsamiane jest dobro wspólne (publiczne). Podstawową przesłanką działań prawodawcy ma być natomiast ochrona tychże wartości ${ }^{47}$. Prawodawca, odwołując się do pojęć

${ }^{42}$ Więcej na ten temat w: P. Machnikowski, Prawne instrumenty ochrony zaufania przy zawieraniu umowy, Wrocław 2010, s. 28-73.

${ }_{43}$ J. Plichta, G. Plichta, Znaczenie zaufania $w$ handlu elektronicznym - perspektywa instytucjonalna, „Psychologia Ekonomiczna” 2013, nr 3, s. 43.

${ }^{44}$ T. Stawecki, Prawo i zaufanie. Refleksja czasu kryzysu, w: J. Oniszczuk (red.), Normalność $i$ kryzys. Jedność czy różnorodność, Warszawa 2010, s. 122 i 125.

${ }_{45}$ A. Młynarska-Sobaczewska, Dobro wspólne jako kategoria normatywna, „Acta Universitatis Lodziensis. Folia Iuridica" nr 69, 2009, s. 63.

${ }^{46}$ Ibidem, s. 72.

${ }^{47}$ L. Góral, Zintegrowany model publicznoprawnych instytucji ochrony rynku bankowego we Francji i Polsce, Warszawa 2011, s. 65. 
nieostrych (dobra wspólnego, interesu publicznego), jak się słusznie uważa, kieruje się przekonaniem o istnieniu określonych wartości, będących dla tych pojęć wspólnym mianownikiem, które muszą zostać zachowane za wszelka cenę, aby zapewnić rozwój społeczeństwa ${ }^{48}$ : „Te wartości, określane jako minimalne, powinny być rozumiane nie tylko jako niezbędne i konieczne, ale traktowane jako wezwanie do osiagnięcia stanu rzeczy, który może być osiagnięty pod warunkiem wystapienia wielu sprzyjających okoliczności. Przyjęcie takiego założenia może przybliżyć wyjaśnienie rozumienia pojęcia interesu ogólnego [dobra wspólnego - T.N.] w przestrzeni rynku finansowego" ${ }^{49}$. Stanowi ono przy tym przesłankę dla podejmowania na nim działań regulacyjnych i kształtowania jego architektury, którą tworzą podmioty na nim funkcjonujace oraz wykorzystywane instrumenty ${ }^{50}$.

Pytanie, jakie pojawia się przy tej okazji, dotyczy kwestii, w czyim interesie prawodawca podejmuje tego rodzaju działania. W interesie państwa, całego rynku, instytucji finansowych na nim obecnych, czy też poszczególnych jego uczestników (przede wszystkim konsumentów)? Jak się okazuje, odpowiedź na to pytanie nie jest jednoznaczna i wymaga indywidualnej oceny danego stanu faktycznego. W procesie tym cenne okazać mogą się wnioski, jakie płyna z rozważań dotyczących różnicy pomiędzy sformułowaniami „dobro wspólne” a „wspólne dobro”. Pierwsze z nich wykorzystał polski prawodawca w art. 1 Konstytucji Rzeczypospolitej Polskiej ${ }^{51}$, który to przepis stanowi, iż „Rzeczpospolita jest dobrem wspólnym wszystkich obywateli”, czyniąc tym samym pojęcie „dobro wspólne” kategorią normatywna. W literaturze przedmiotu sygnalizowana jest różnica, jaka wynika z układu słów „dobro” i „wspólne”. Nie wchodząc w szczegółowe rozważania na ten temat, różnicę pomiędzy „dobrem wspólnym” a „wspólnym dobrem” można wytłumaczyć motywacją aktywności podmiotu dążącego do ich osiagnięcia. O ile w pierwszym przypadku akcentowany jest aspekt uniwersalny - obiektywny (a więc podejmowane działania służyć mają szerszej grupie osób), o tyle w przypadku wspólnego dobra, jak się uważa, podejmuje się przede wszystkim działania w celu poprawy swojej (ewentualnie jeszcze kilku podmiotów) sytuacji ${ }^{52}$. Odnosząc zaprezentowane różnice do relacji państwo-jednostka, optyka w przypadku pojęcia wspólnego dobra koncentruje się na państwie - jego dobru, a działania członków tworzącej go wspólnoty mają służyć właśnie państwu. Z odmienną sytuacja mamy do czynienia w sytuacji użycia pojęcia „dobro wspólne”, które odnoszone jest do tradycji klasycznej. W tradycji tej, jak pisze M. Piechowiak, aby wiedzieć, co jest dobrem wspólnym, należy posiadać wiedzę na temat tego, co służy rozwojowi człowieka. Należy wiedzieć, kim on jest, spojrzeć na niego przez pryzmat

48 Ibidem, s. 66.

49 Ibidem.

${ }^{50} \mathrm{~S}$. Voight, Do we need a new international financial architecture? Many questions and some preliminary advice, w: R. Grote, T. Marauhn (eds.), The Regulation of International Financial Markets. Perspective for Reform, Cambridge 2008, s. 277-294.

${ }^{51}$ Konstytucja Rzeczypospolitej Polskiej z 2 kwietnia 1997 r., Dz. U. 1997, Nr 78, poz. 483 ze zm.

52 Z. Stawrowski, Dobro wspólne a filozofia polityki, w: W. Arnd, ks. F. Longchamps de Bérier, K. Szczucki (red.), Dobro wspólne. Teoria i praktyka, Warszawa 2013, s. 14-15. 
rzeczywistości pozaprawnej i na podstawie tej obserwacji stanowić prawo. Prawo i państwo mają być więc dla człowieka ${ }^{53}$. Koncepcja ta jest szczególnie ważna także dla prawa regulujaccego rynek finansowy, które postrzegane instrumentalnie, a więc jako zjawisko złożone, uwzględniać musi rozmaite czynniki, w tym behawioralne.

Przyjmując, że Rzeczpospolita jako państwo jest dobrem wspólnym wszystkich obywateli, można stwierdzić, iż rynek finansowy, będąc - jak zostało to wykazane - jednym z najistotniejszych elementów systemu państwowego, stanowi część tego dobra. Państwo bowiem, jak słusznie się uważa: ,jest dobrem wspólnym nie wbrew interesom społecznym, lecz właśnie dlatego, że stanowi forum ich artykulacji” 54 . Dopuszcza się przy tym sytuacje, w których interes indywidualny może nie być do pogodzenia z dobrem wspólnym i tym samym rodzić konieczność wyważenia proporcji pomiędzy prawami i wolnościami jednostki a niezbędnymi ograniczeniami swobód z uwagi na to, co wspólne. „Formuła dobra wspólnego akcentuje bowiem doniosłość interesu publicznego"55. Teza ta może znaleźć swoje uzasadnienie w przypadku rynku finansowego, w sytuacji gdy konieczne będzie wyważenie interesów określonej grupy osób, która przykładowo poniosła szkodę wskutek działań instytucji finansowych oraz interesu ogółu, w tym przypadku społeczeństwa zagrożonego skutkami utraty stabilności przez system finansowy.

Problem ten był przedmiotem przytoczonej już w niniejszej publikacji sprawy Peter Paul i inni przeciwko Republika Federalna Niemiec (C-222/02) ${ }^{56}$, rozpatrywanej przed TSUE. W treści pkt 47 uzasadnienia wyroku w tej sprawie Trybunał przewidział możliwość istnienia nadrzędności interesu publicznego nad interesem indywidualnym, wyłączając tym samym w określonych sytuacjach możliwość ubiegania się przez osoby fizyczne o naprawienie szkody z tytułu zaniedbania ze strony organu nadzoru nad rynkiem finansowym ${ }^{57}$. Mimo że dopuścić powinno się tego rodzaju sytuację, to jednak zgodzić się należy z teza, że w każdym przypadku podmiot korzystający z nadrzędności interesu ogólnego nad interesem indywidualnym musi wykazać istotność interesu ogólnego (publicznego) i udowodnić, „iż jest on na tyle ważny i znaczący, że bezwzględnie wymaga ograniczenia uprawnień indywidualnych obywateli"58. Co więcej, jak słusznie uważa Aleksandra Wilczyńska, ocena danego stanu faktycznego pod kątem interesu publicznego i konsekwencji wynikajacych z powołania się na niego powinna brać pod uwage społeczne uzasadnienie takich, a nie innych

${ }^{53}$ M. Piechowiak, Prawne a pozaprawne pojęcia dobra prawnego, w: W. Arnd, ks. F. Longchamps de Bérier, K. Szczucki (red.), op. cit., s. 25; odmienny pogląd wyraża W. Brzozowski, Konstytucyjna zasada dobra wspólnego, „Państwo i Prawo” 2006, z. 11, s. 19-20.

${ }^{54}$ W. Brzozowski, op. cit., s. 24.

55 Ibidem.

${ }_{56}$ Wyrok ETS z 12 października 2004 r. w sprawie C-222/02, Peter Paul i inni przeciwko Republika Federalna Niemiec, ECR 2004, s. I-9425.

57 W literaturze przedmiotu spotkać można się z koncepcja, według której w państwie prawa idea interesu społecznego i interesu publicznego są znaczeniowo tożsame i nie są tożsame $\mathrm{z}$ pojęciem interesu państwa. Zob. A. Duda, Interes prawny w polskim prawie administracyjnym, Warszawa 2008, s. 24.

58 S. Fundowicz, Aksjologia prawa administracyjnego, w: J. Zimmermann (red.), Koncepcja systemu prawa administracyjnego, Warszawa 2007, s. 649. 
działań z punktu widzenia korzyści, które mogą one przynieść przy jednoczesnej relatywizacji względem konkretnego układu wartości, z uwagi na który nadawany jest temu interesowi publiczny wymiar ${ }^{59}$. Jeżeli przyjąć zaprezentowana wcześniej tezę o ujmowaniu zaufania jako wartości naczelnej rynku finansowego, identyfikowanej jako kategoria integralnego dobra wspólnego - potencjalnymi korzyściami jego ochrony będą bezpieczeństwo i stabilność systemu finansowego. Konflikt pomiędzy interesem publicznym a indywidualnym jest jednym $\mathrm{z}$ wielu, jakie mogą wystapić $\mathrm{w}$ procesie poszukiwania dobra wspólnego ${ }^{60}$. W odniesieniu do rynku finansowego Unii Europejskiej, który tworzą rynki finansowe państw członkowskich, innym potencjalnym obszarem konfliktu może być sytuacja, w której na szali postawiony zostanie interes unijny i krajowy. Może do tego dojść, gdy organy tworzące Europejski System Nadzoru Finansowego ${ }^{61}$ zdecydowałyby się na wydanie tzw. decyzji europejskich, za pomoca których ingerowałyby w działania zastrzeżone dotychczas dla krajowych organów nadzo$\mathrm{ru}^{62}$. W zależności od następstw tego rodzaju decyzji wyobrazić można sobie bowiem sytuację naruszenia bądź to interesu (dobra) unijnego, bądź też interesu (dobra) krajowego z wszelkimi tego konsekwencjami.

\section{PODSUMOWANIE}

Powyższe rozważania na temat relacji, jakie istnieja pomiędzy rynkiem finansowym a dobrem wspólnym, pozwalają stwierdzić, że rynek ten jako część państwa może być sam w sobie traktowany jako dobro wspólne wszystkich obywateli. Jego stabilny i bezpieczny rozwój zapewnia bowiem państwu (a więc i obywatelom) dobrobyt, do którego kreacji przyczyniają się kapitały płynące z tego rynku. Rynek finansowy ujmowany może być także jako struktura, na którą składają się inne dobra wspólne (wartości), w tym przede wszystkim zaufanie, postrzegane jako jedno z najważniejszych aktywów instytucji finansowych, które zdobywane latami, może zostać utracone niezwykle szybko. Dlatego aby budować stabilność rynku, należy szczególną uwagę poświęcić podmiotowi, bez którego istnienie tego rynku nie miałoby racji bytu. Mowa w tym miejscu o człowieku. W procesie budowy zaufania do rynku dużą rolę odgrywa proces tworzenia, ale także i stosowania prawa. W tym ostatnim przypadku niejednokrotnie, jak zostało to wykazane, pojawić może się konflikt pomiędzy interesem ogółu a interesem jednostki. Za każdym razem jego rozstrzygnięcie wymaga kompleksowej oceny danego stanu faktycznego, a także znajomości

59 A. Wilczyńska, Interes publiczny w prawie stanowionym i orzecznictwie Trybunału Konstytucyjnego, „Przegląd Prawa Handlowego” 2009, nr 6, s. 49. Zob. także A. Żurawik, „Interes publiczny”, „interes społeczny” $i$,interes społecznie uzasadniony”. Próba dookreślenia pojęć, „Ruch Prawniczy, Ekonomiczny i Socjologiczny” 75, 2013, z. 2, s. 60-62.

60 Szczegółowo omówione zostały one w: A. Wilczyńska, op. cit., s. 49-53.

${ }^{61}$ Więcej na ten temat w: M. Fedorowicz, Nadzór nad rynkiem finansowym Unii Europejskiej, Warszawa 2013, passim.

${ }^{62}$ M. Fedorowicz, A. Michór, O charakterze prawnym decyzji nowych europejskich organów nadzoru nad rynkiem finansowym UE, „Europejski Przegląd Sądowy” 2011, nr 11, s. 24-35. 
zasad funkcjonowania rynku finansowego. Ważne jest także uwzględnienie wątków aksjologicznych. Na konieczność sięgnięcia do źródeł i uwzględnienia wartości zwraca uwage coraz częściej także Unia Europejska. Za przykład posłużyć może opracowana niedawno opinia Europejskiego Komitetu Ekonomiczno-Społecznego w sprawie: „Gospodarka na rzecz dobra wspólnego - zrównoważony model gospodarczy ukierunkowany na spójność społeczną"63. W dokumencie tym znalazły się propozycje rewolucyjne, takie jak: opracowanie pomiaru wkładu przedsiębiorstw we wspólne dobro za pomoca opracowania bilansu dobra wspólnego, wprowadzenie oznakowania etycznego na sprzedawanych produktach, a także poszerzenie zakresu umowy bazylejskiej o etyczne kryteria jakości w obszarze uregulowań bankowych. Można więc żywić nadzieję, że dotychczasowe rozważania akademickie na temat bonum commune i rynku finansowego znajdą przełożenie na rzeczywistość. Jak bowiem stwierdził Arystoteles: „Bonum est quod omnia appetunt” („Dobro jest tym, czego wszystkie byty pożądają" $)^{64}$.

dr hab. Tomasz Nieborak

Profesor Uniwersytetu im. Adama Mickiewicza w Poznaniu

nieborak@amu.edu.pl

\section{A FINANCIAL MARKET AS THE COMMON GOOD}

\section{Sum mary}

This article addresses a very topical and important issue which is the defining of the financial market as the common good. Being a part of the economic and social system, the financial market is one of the most important elements of the functioning of a State. The events of the recent years when the financial crisis shook the foundations of the contemporary world have confirmed this thesis. What led to this crisis was, among other things, greed for money and depreciation of certain values as well as inefficient enforcement of law and a lack of a deeper reflexion on the potential consequences of a collapse of the financial market. However, crises have a purifying effect as well. This reflection became an inspiration for writing this paper and to posit that a financial market must also be seen as the common good. Apart from a theoretical value and dimension this thesis has a strong practical implication and may be adopted in court practice.

${ }^{63}$ OJ C 2016 013/06.

${ }^{64}$ Arystoteles, Etyka nikomachejska 1094a, Warszawa 1996, s. 77. Zob. także J. Boć, Z refleksji nad dobrem wspólnym, w: idem, A. Chajbowicz (red.), Nowe problemy badawcze $w$ teorii prawa administracyjnego, Wrocław 2009, s. 151-154. 